\title{
Paradoxical embolism in a young man: a case report
}

\author{
Ana Antonić*, \\ - $L$ Lea Skorup Ćutić, \\ - IIvana Smoljan, \\ OTamara Hlača Caput, \\ - Sanja Matijević \\ Rončević, \\ -Petra Bulić, \\ Olvana Grgić Romić, \\ CKoraljka Benko, \\ ㄷTomislav Jakljević, \\ @Alen Ružić, \\ (CLuka Zaputović, \\ DTeodora Zaninović \\ Jurjević
}

University of Rijeka, Faculty of Medicine, University Hospital Centre Rijeka, Rijeka, Croatia

\author{
KEYWORDS: paradoxical embolism, patent foramen ovale, pulmonary embolism. \\ CITATION: Cardiol Croat. 2021;16(5-6):189. | https://doi.org/10.15836/ccar2021.189
}

*ADDRESS FOR CORRESPONDENCE: Ana Antonić, Klinički bolnički centar Rijeka, Tome Strižića 3, HR-51000 Rijeka, Croatia. / Phone: +385-51-407225 / E-mail: aantonic326@gmail.com

ORCID: Ana Antonić, https://orcid.org/0000-0002-5767-1206 • Lea Skorup Ćutić, https://orcid.org/0000-0003-2246-0908 Ivana Smoljan, https://orcid.org/0000-0002-9668-291X • Tamara Hlača Caput, https://orcid.org/0000-0002-7749-0031 Sanja Matijević Rončević, https://orcid.org/0000-0003-0627-2114 • Petra Bulić, https://orcid.org/0000-0002-5219-1836 Ivana Grgić Romić, https://orcid.org/0000-0002-0035-4445 • Koraljka Benko, https://orcid.org/0000-0001-7556-0860 Tomislav Jakljević, https://orcid.org/0000-0002-3692-0111 • Alen Ružić, https://orcid.org/0000-0001-5031-2975 Luka Zaputović, https://orcid.org/0000-0001-9415-9618 • Teodora Zaninović Jurjević, https://orcid.org/0000-0001-8359-3910

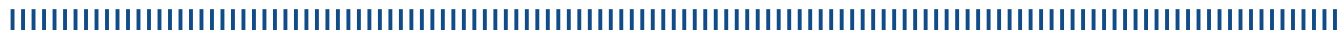

Introduction: Paradoxical embolism referring to venous thromboembolism traversing through intracardiac shunt into systemic circulation is an important clinical entity. ${ }^{1}$ Depending on the site of embolism it can result in ischemic stroke, myocardial infarction, embolization of abdominal or limb arteries. It represents around $2 \%$ of all cases of arterial embolizations. ${ }^{2}$ Patent foramen ovale is the most common intracardiac shunt that can be found in up to $30 \%$ of population and its presence is strongly related to paradoxical embolism..$^{1,2}$

Case report: 44-year-old male with no significant medical history was admitted to Emergency Department because of left arm pain and coldness with absent radial pulse. In addition, patient reported exertional dyspnea over the past three days. Examination and imaging revealed thromboembolism of distal part of left subclavian artery, axillar and brachial artery with saddle pulmonary embolism (PE) and embolism in distal parts of left and right pulmonary arteries, lobar, segmental and subsegmental arteries with deep popliteal vein thrombosis. Initial echocardiographic examination showed right ventricular dysfunction with interatrial septal aneurism and suspected defect. Although PE was of intermediate low risk it was decided to apply systemic thrombolysis (using recombinant tissuetype plasminogen activator). Therapy went without complications with complete resorption of saddle thrombus in main pulmonary artery with only partial resorption of arm thrombus, so Fogarty arterial embolectomy was indicated. Transesophageal echocardiography with agitated saline injection and Valsalva maneuver revealed patent foramen ovale. After initial treatment with therapeutic dose of enoxaparin rivaroxaban was initiated.

Conclusion: In a case of concomitant venous and arterial embolization it is important to search for intracardiac shunts. Transesophageal echocardiography is reference method in shunt detection. Treatment of paradoxical embolism includes antithrombotic and anticoagulant treatment, percutaneous closure devices or surgical treatment.
RECEIVED:

March 28, 2021

ACCEPTED:

April 2, 2021

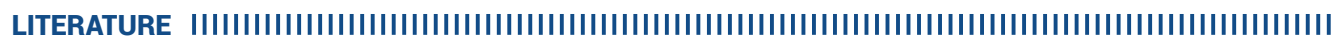

1. Windecker S, Stortecky S, Meier B. Paradoxical embolism. J Am Coll Cardiol. 2014 Jul 29;64(4):403-15. https://doi.org/10.1016/j.jacc.2014.04.063

2. Mirarchi FL, Hecker J, Kramer CM. Pulmonary embolism complicated by patent foramen ovale and paradoxical embolization. J Emerg Med. 2000 Jul;19(1):27-30. https://doi.org/10.1016/S0736-4679(00)00177-3
Cardiologia Croatica $\square$ 2021;16(5-6):189 